\title{
PENGEMBANGAN AGROWISATA BERBASIS KETAHANAN PANGAN MELALUI STRATEGI KOMUNIKASI PEMASARAN DI DESA SERANG PURBALINGGA
}

\section{AGRITOURISM DEVELOPMENT BASED ON FOOD SECURITY THROUGH MARKETING COMMUNICATION STRATEGY IN SERANG PURBALINGGA}

\author{
Adhi Iman Sulaiman, Bambang Kuncoro, Endang Dwi Sulistyoningsih, Hikmah \\ Nuraeni, Fatmah Siti Djawahir \\ (adhi_iman@yahoo.com, bkun@ymail.com, endang_sulistyo58@yahoo.co.id, \\ noer_in96@yahoo.com, fatmah40@yahoo.co.id) \\ (FISIP, Universitas Jenderal Soedirman)
}

\begin{abstract}
Abstrak
Tujuan studi ini untuk menganalisis pengembangan agrowisata berdasarkan pada ketahanan pangan melalui strategi komunikasi pemasaran. Metode penelitian yang digunakan yakni Participatory Rural Apprasial, yang mana data dikumpulkan melalui wawancara, observasi, pendokumentasian dan focus group discussion, dengan analisis secara interaktif dan SWOT. Informan penelitian diambil melalui teknik purposive sampling dari 30 orang yang tergabung dalam komunitas pekerja di Desa Serang, Kecamatan Karangrejo, Kabupaten Purbalingga. Hasil penelitian menunjukkan bahwa upaya aparat desa belum mampu mengelola organisasi, pemasaran, promosi, pengembangan unit-unit bisnis dan kemitraan, sehingga membutuhkan model komunikasi pemasaran terintegrasi melalui pemberdayaan agrowisata berbasis ketahanan pangan di Desa Serang.
\end{abstract}

Kata Kunci: Ekowisata, Ketahanan Pangan, Pengetahuan Lokal, Komunikasi Pemasaran, Pemberdayaan

\begin{abstract}
The study aims to analyze the developing agrotourism based on food security through marketing communications strategy. The research method used Participatory Rural Apprasial, data was collected through interviews, observation, documentation and focus group discussion with interactive analysis and SWOT analysis. The informant research through purposive sampling of 30 people as a community worker in the Serang village, Karangreja subdistrict of Purbalingga Regency. The results showed corporation effort possession village have not been able to manage the organization, marketing, promotion, developing business units and partnerships, thus require integrated marketing communications model on the empowerment of agrotourism based on food security in the Serang village.
\end{abstract}

Keywords: Ecotourism, Food Security, Local Knowledge, Marketing Communication, Empowerment

\section{Pendahuluan}

Provinsi Jawa Tengah dalam Buku Pegangan Perencanaan Pembangunan Daerah 2014 bertema "Memantapkan Perekonomian Nasional bagi Peningkatan Kesejahteraan Rakyat yang Berkeadilan” yang diterbitkan oleh Kementerian Perencanaan Pembangunan Nasional/ Badan Perencanaan Pembangunan Nasional tahun 2013, telah menempatkan pada urutan pertama isu strategis pembangunan tentang stabilisasi produksi pangan untuk keberlanjutan ketahanan pangan dan perioritas pembangunan pada (1) Menurunkan angka kemiskinan; (2) Memantapkan ketahanan pangan.

Kemudian berdasarkan Laporan Penerapan dan Pencapaian Standar Pencapaian Minimal Bidang Ketahanan Pangan di Provinsi Jawa Tengah tahun 2013 bahwa pangan merupakan kebutuhan dasar bagi kehidupan manusia. Untuk itu pemenuhan kebutuhan pangan menjadi hal 
penting dalam keberlanjutan penghidupan bagi masyarakat. Pembangunan ketahanan pangan ditujukan menjamin ketersediaan, keterjangkauan, dan konsumsi pangan yang cukup, aman, bermutu, bergizi, dan seimbang bagi setiap individu.

Ketahanan pangan menjadi program pembangunan pemerintah yang bukan slogan kebijakan publik bersifat populis serta utopis yang tidak membumi. Tetapi program karena ketahanan pangan ditujukan mulai dari tingkat pemerintah pusat melalui kemauan dan dukungan (political will) kebijakan program serta anggarannya sampai ke tingkat daerah. Menurut Undang-Undang Rublik Indonesia Nomor 18 tahun 2012 tentang Pangan, pada Pasal 1 bahwa ketahanan pangan adalah kondisi terpenuhinya Pangan bagi negara sampai dengan perseorangan, yang tercermin dari tersedianya Pangan yang cukup, baik jumlah maupun mutunya, aman, beragam, bergizi, merata, dan terjangkau serta tidak bertentangan dengan agama, keyakinan, dan budaya masyarakat, untuk dapat hidup sehat, aktif, dan produktif secara berkelanjutan. Pasal 3 bahwa penyelenggaraan Pangan dilakukan untuk memenuhi kebutuhan dasar manusia yang memberikan manfaat secara adil, merata, dan berkelanjutan berdasarkan Kedaulatan Pangan, Kemandirian Pangan, dan Ketahanan Pangan.

Menurut Undang-Undang Nomor 41 tahun 2009 tentang Perlindungan Lahan Pertanian Pangan Berkelanjutan pada Pasal 1 bahwa Ketahanan Pangan adalah kondisi terpenuhinya pangan bagi rumah tangga yang tercermin dari tersedianya pangan yang cukup, baik jumlah maupun mutunya, aman, merata, dan terjangkau. Kemandirian Pangan adalah kemampuan produksi pangan dalam negeri yang didukung kelembagaan ketahanan pangan yang mampu menjamin pemenuhan kebutuhan pangan yang cukup ditingkat rumah tangga, baik dalam jumlah, mutu, keamanan, maupun harga yang terjangkau, yang didukung oleh sumber-sumber pangan yang beragam sesuai dengan keragaman lokal.

Terdapat permasalahan dalam pemberdayaan ketahanan pangan lokal, yaitu dari Kementerian Negara Riset dan Teknologi RI 2005 - 2025 dalam Buku Putih Penelitian, Pengembangan dan Penerapan Ilmu Pengetahuan dan Teknologi Bidang Ketahanan Pangan Tahun 2006 salah satunya menjelaskan bahwa (1) Kebutuhan pangan masyarakat lebih tinggi dari kapasitas produksi dalam negeri; (2) Pengurangan luasan lahan pertanian produktif akibat konversi penggunaannya untuk kepentingan nonpertanian; (3) Pola konsumsi yang masih sangat didominasi oleh beras, upaya diversifikasi pangan masih terkendala oleh keterbatasan pengetahuan dan keterjangkauan; (4) Pasokan pangan hingga tingkat rumah tangga sering terhambat sebagai akibat dari keterbatasan jaringan transportasi; (5) Beberapa produk pangan tidak tersedia sepanjang tahun karena siklus produksi alami jenis komoditas pangan yang dibudidayakan, faktor agroklimat, dan belum berkembangnya agroindustri untuk pengolahan atau pengawetannya; (6) Masih sering dijumpai produk pangan yang tidak memenuhi standar kesehatan pangan dan/atau sesuai dengan syarat kehalalannya; (7) Belum semua rumah tangga secara ekonomi mampu memenuhi kebutuhan pangan pokoknya; (8) Marjin keuntungan usahatani tanaman pangan sangat kecil, sehingga sangat menghambat motivasi petani untuk meningkatkan produksinya.

Ketahanan pangan menjadi program pembangunan pemerintah yang bukan slogan kebijakan publik bersifat populis serta utopis yang tidak membumi. Tetapi program karena ketahanan pangan ditujukan mulai dari tingkat pemerintah pusat melalui kemauan dan dukungan (political will) kebijakan program serta anggarannya sampai ke tingkat daerah. 
Implementasi kebijakan peningkatan produksi tanaman lokal belum optimal sehingga masih terdapat kesenjangan yang besar antara produksi dengan potensi tanaman pangan lokal. Beberapa masalah mendasar yang perlu mendapat perhatian yaitu masalah kurangnya pelibatan para implementor pada tataran operasional, masalah koordinasi pelaksanaan antar unit dan masalah anggaran yang memadai untuk program peningkatan produksi tanaman pangan lokal (Nursalam, 2010: 66-77). Kebijakan bidang ketahanan pangan hanya dinilai sebagai pembangunan fisik, dengan memberikan bantuan material yang hanya bermanfaat sesaat saja. Perlu mengkaji persoalan yang selalu muncul yaitu faktor sosial budaya dan memperhatikan kearifan lokal masyarakat sebagai modal pembangunan (Wirawan dan Nurdin, 2013: 45-56).

Menurut hasil riset Kuncoro et al. (2015: 461-471), katahanan pangan lokal di masyarakat Desa Serang menjadi kearifan lokal (local wisdom) yang khas dan unik yaitu budaya menanam holtikultura di pekarangan rumah dan di lahan perkebunan sudah sejak lama secara turun temurun untuk mencukupi kebutuhan keluarga (harian) dan untuk dijual secara massal serta komersial. Masyarakat selalu menyepakati menanam jenis komoditas holtikultura tertentu di ladang secara massal dan komersial. Apabila ada keuntungan dan kerugian seperti terjadi gagal panen ditanggung secara berama. Artinya tidak ada yang mengalami keuntungan dan kerugian secara sepihak, tidak ada persaingan produk dan pemasaran antar petani di masyarakat secara terbuka. Desa Serang merupakan lokasi agrowisata di Purbalingga yang selalu mendapat kunjungan wisatawan, perkemahan, pelatihan dan permainan outbound serta menjadi tempat kegiatan ilmiah seperti riset, pengabdian masyarakat dan praktek kerja bagi perguruan tinggi.
Desa Serang banyak mendapat kegiatan pemberdayaan masyarakat dari perguruan tinggi, pemerintah daerah, pemerintah nasional dan Non Governmental Organizations (NGOs) untuk meningkatkan pengetahuan kemampuan dan kelembagaan ekonomi. Hasil studi lanjutan tahun 2016 menemukan beberapa permasalahan di Desa Serang yaitu komunikasi pemasaran produk hasil panen holtikultura terutama stroberi masih bersifat monompoli, artinya terjalin komunikasi jual beli antara petani dengan bandar pembeli atau tengkulak yang menguasai pemasaran sejak lama menjadi mitra para petani. Petani tidak memiliki keberanian untuk melakukan komunikasi pemasaran dengan pihak lain seperti memasarkan secara langsung ke pasar-pasar atau mencari pembeli lain yang bisa menaikan harga secara kompetitif. Masyarakat menjungjung tinggi budaya saling menghormati, menjalin hubungan baik serta kesetiaan bermitra dengan pembeli tetap yaitu tengkulak. Akibatnya petani dalam pemasaran produknya tidak dapat menentukan harga sendiri, tetapi menuruti harga yang ditentukan tengkulak, jika terjadi harga turun secara drastis maka petani pasrah mengalami kerugian secara bersama. Desa Serang memiliki letak wilayah di pegunungan dan komoditas hasil pertanian holtikulturanya, sehingga menjadi kawasan agrowisata yang potensial dan prospektif. Desa serang telah memiliki perusahaan bersama yaitu Badan Usaha Milik Desa Serang Makmur Sejahtera (BUMDes SMS) dengan unit usaha unggulan yaitu agrowisata yang menyediakan lokasi taman bunga, sayuran dan stroberi, tempat bermain, warungwarung makanan, rest area untuk transit pelintasan akses jalur tengah dari Kabupaten Purbalingga ke daerah pantura khususnya Kabupaten Tegal, arena berkuda, perkemahan, outbound untuk pelatihan dan olah raga. Produk hasil sayuran dan olahan strowberi belum dapat 
dikemas serta dipasarkan secara lebih kompetitif. Promosi, pelayanan pengunjung, dan informasi agrowisata masih belum maksimal dilakukan. Dengan demikian tempat agrowisata di Desa Serang masih membutuhkan pelatihan dan pendampingan tentang menjemen organisasi, administrasi, pengelolaan unit usaha dan keuangan, strategi promosi serta pemasaran.

Dengan demikian di Desa Serang sebagai kawasan agrowisata berbasis ketahanan pangan membutuhkan strategi komunikasi pemasaran terpadu (Integrated Marketing Communication Strategy). Menurut Soemirat dan Ardianto (2010) dalam marketing terlebih dahulu melakukan perencanaan yang jelas dan menentukan sasaran atau target dengan penerapan strategi dan taktik promosi untuk melakukan pemasaran. Takalani (2015) menjelaskan Integrated Marketing Communication (IMC) merupakan pengembangan dalam strategi komunikasi yaitu harus mengontrol perencanaan atau mempengaruhi pesan, suatu produk, dan layanan untuk memastikan konsistensi pesan tersebut, sehingga memiliki dampak komunikasi yang maksimal.

Kementerian Negara Riset dan Teknologi RI 2005 - 2025 dalam Buku Putih Penelitian, Pengembangan dan Penerapan Ilmu Pengetahuan dan Teknologi Bidang Ketahanan Pangan Tahun 2006 bahwa pembangunan ketahanan pangan merupakan tanggung jawab bersama antara pemerintah dan masyarakat.

Pemerintah menyelenggarakan pengaturan, pembinaan, pengendalian, dan pengawasan terhadap ketersediaan pangan yang cukup, baik jumlah maupun mutunya, aman, bergizi, beragam, dan merata; dan masyarakat memiliki kesempatan untuk berperan serta seluas-luasnya dalam mewujudkan ketahanan pangan. Peran serta masyarakat dapat berupa: (1) melaksanakan produksi, perdagangan, dan distribusi pangan; (2) menyelenggarakan cadangan pangan masyarakat; (3) melakukan pencegahan dan penanggulangan masalah pangan.

Berdasarkan hal tersebut, penting dan menarik untuk melakukan kajian tentang pengembangan agrowisata berbasis ketahan pangan melalui strategi komunikasi pemasaran di Desa Serang Kecamatan Karangreja Kabupaten Purbalingga. Desa Serang sebagai lokasi agrowisata dan ketahanan pangan yang menerima pengahragaan Pakarti Utama I Tingkat Nasional Pelaksana Terbaik Pemanfaatan Halaman Pekarangan pada Tahun 2013.

\section{Metodologi}

Penelitian menggunakan metode Participatory Rural Apprasial (PRA) yang menekankan pengetahuan lokal dan kemampuan masyarakat untuk membuat penilaian, menganalisis dan merencanakan sendiri apa yang dibutuhkan dengan proses saling berbagi informasi (information sharing), analisis dan aktifitas antar stakeholders (Syahyuti, 2006). Pengumpulan data penelitian dari analisis dokumen, hasil observasi langsung, penyebaran angket dan wawancara serta melalui Focus Group Discussion (FGD).

Lokasi penelitian dipilih Desa Serang Kecamatan Karangreja Kabupaten Purbalingga yang secara potenisal dan aktual sebagai lokasi agrowisata berbasis ketahanan pangan. Pemilihan informan secara purposif sampling yaitu para pengurus BUMDes dan agrowisata, kelompok usaha dan kelompok tani.

Menggunakan analisis data model interaktif dari Miles dan Huberman (2007) yang terdiri dari tiga tahap yaitu reduksi data, penyajian data dan penarikan kesimpulan atau verifikasi. Kemudian membuat strategi dengan menggunakan analisis SWOT.

\section{Hasil dan Pembahasan}

Karakteristik Desa Serang sebagai daerah agrowisata berbasis ketahanan 
pangan yaitu menjadi sentra (pusat) holtikultura di Purbalingga. Desa Serang memiliki tradisi terun temurun sejak lama dalam ketahanan pangan lokal karena didukung oleh letak daerah yang berada di dataran tinggi dengan ketinggian sekitar 650 - $1.600 \mathrm{~m}$ dpl, serta curah hujan yang cukup tinggi sekitar $6,240 \mathrm{~mm}$ dengan suhu rata-rata $20^{\circ} \mathrm{C}$. Berdasarkan data dari monograf Desa Serang yaitu wilayah tanah yang cukup subur dengan luas desa 2,878.390 ha. Desa Serang memiliki lahan pertanian dan perkebunan yang luas dengan seluruh wilayahnya terdapat tanaman sayuran dan juga terdapat tanaman buah unggulan. Komoditas utama komoditas holtikultra di Desa Serang dengan luas lahan yaitu jagung 16,75 ha, padi ladang 16 ha, ubi kayu 20 ha, ubi jalar 8 ha, cabe 3 ha, tomat 4 ha, sawi 23 ha, kentang 12,6 ha, kubis 22 ha, mentimun 1 ha, buncis 5 ha, wortel 30 ha, stroberi 64 ha. Desa Serang memiliki kegiatan yang sudah menjadi tradisi yaitu panen raya yang biasanya pada pertengahan AgustusSeptember. Menurut kepala Desa Serang, agrowisata dengan kebun stroberi dan rest area memberikan dampak positif terhadap ekonomi masyarakat, seperti satu hektar kebun stroberi, bila dikunjungi 2.000 orang bisa menghasilkan pendapatan 30 juta. Desa Serang dengan jumlah petani 454 orang, dengan produksi stroberi mencapai 1,5 ton sampai 2 ton sehari.

Masyarakat Desa Serang memiliki pengalaman yang menjadi budaya turun temurun di bidang pertanian holtikultura termasuk pemanfaatan pekarangan disekitar rumah atau ketahanan pangan lokal. Ketahanan pangan lokal di Desa Serang memiliki manfaat untuk mencukupi kebutuhan harian keluarga, menambah penghasilan, dan daya tahan terhadap krisis ekonomi ketika harga-harga barang pokok naik serta ketika adanya gagal panen raya karena hama tanaman serta rendahnya harga di pasar. Ashari et al. (2012: 13-30) menyatakan upaya membangun ketahanan pangan keluarga salah satunya dapat dilakukan dengan memanfaatkan sumber daya yang tersedia diantaranya melalui pemanfaatan katahanan lahan pekarangan. Pemanfaatan lahan pekarangan memiliki potensi dalam penyediaan bahan pangan keluarga, mengurangi pengeluaran rumah tangga untuk pembelian pangan dan meningkatkan pendapatan rumah tangga petani. Menurut Saliem (2011: 1-10) salah satu upaya untuk meningkatkan ketahanan pangan dan gizi keluarga dapat dilakukan melalui pemanfaatkan sumber daya yang tersedia maupun yang dapat disediakan di lingkungannya. Upaya tersebut dapat dilakukan melalui pemanfaatan lahan pekarangan yang dikelola oleh rumah tangga untuk mewujudkan kemandirian pangan. Cepriadi dan Yulida (2012: 177194) menegaskan bahwa memaksimalkan pemanfaatan lahan-lahan sebagai media untuk menanam komoditi-komoditi yang dapat dimanfaatkan untuk pemenuhan kebutuhan harian masyarakat, pemberdayaan masyarakat terutama kaum ibu rumah tangga dan dapat membantu menambah pendapatan rumah tangga.

Walaupun masyarakat Desa Serang sudah memiliki tradisi secara turun temurun dan berpengalaman dalam pemanfatan lahan pekaranan sebagai ketahanan pangan, namun tetap membutuhkan program pemberdayaan yang terpadu atau terintegrasi dengan memberikan sosialisasi, penyuluhan, pelatihan, pendampingan, dan adopsi inovasi khususnya tentang ketahanan pangan untuk menambah motivasi, pengetahuan, kemampuan dan penguatan kelembagaan kelompok ketahanan pangan sebagai komoditas unggulan yang menarik dan unik serta lebih bermanfaat menjadi sumber obat herbal atau disebut Tanaman Obat Keluarga (Toba) yang mendukung dalam strategi promosi dan pemasaran agrowisata. Terdapat keterkaitan atau kesamaan antara pemberdayaan dengan ciri komunikasi pemasaran terpadu, sebagaimana menurut Belch dan Belch 
(2004) ciri komunikasi pemasaran yaitu mempengaruhi perilaku pelanggan dan calon pelanggan, melakukan komunikasi, berusaha menciptakan sinergi, dan menjalin hubungan. Menurut Mardikanto dan Soebianto (2012) pemberdayaan sebagai upaya yang disengaja untuk memfasilitasi masyarakat lokal dalam merencanakan, memutuskan, dan mengelola sumber daya lokal yang dimiliki melalui collective action dan networking, sehingga pada akhirnya masyarakat memiliki kemampuan dan kemandirian secara ekonomi, ekologi dan sosial. Hughes dan Fill (2005) menyatakan dalam komunikasi pemasaran terdapat proses manajemen yang dilakukan organisasi untuk berdialog dengan khalayak. Berdasarkan pemahaman tentang lingkungan komunikasi khalayak untuk mengembangkan dan menyajikan pesan, mengidentifikasi kelompok pemangku kepentingan, mengevaluasi dan bertindak atas tanggapan khalayak. Wibowo et al. (2012: 262-271) menjelaskan pentingnya program ketahanan pangan sebagai berikut: (1) Mempertahankan dan meningkatkan produktivitas lahan dengan memanfaatkan sumber daya lokal, seperti jenis tanaman potensial, bibit unggul lokal, pupuk hijau, kompos dan pupuk hayati; Meningkatkan diversifikasi tanaman pangan; (3) Optimalisasi usaha tani terpadu (integrated system farming) melalui sistem ternak tanaman, perikanantanaman yang dipadukan dengan usaha peningkatan produksi tanaman; (4) Mengolah dan menanami lahan pekarangan dengan jenis tanaman yang bermanfaat seperti tanaman obat keluarga dan diadaptasikan dengan kondisi lokal, serta memanfaatkan adopsi teknologi yang dilaksanakan oleh petani; Meningkatkan pendampingan, pemanduan dan pelatihan bagi petani serta kelompok tani guna meningkatkan kemandirian petani; (6) Meningkatkan peran wanita dalam usahatani; (7) Melaksanakan survei dan pemetaan ketersediaan dan kerawanan pangan yang bertujuan untuk memperoleh gambaran yang sebenarnya terhadap kondisi pangan.

Desa Serang selain memiliki ketahanan pangan lokal secara mikro di pekarangan rumah, juga terdapat komoditas holtikultura unggulan dengan produksi massal yang dapat dipasarkan secara komersil dan musiman. Hortikultura (horticulture) berasal dari bahasa Latin yaitu hortus artinya tanaman kebun dan cultura atau colere artinya budidaya, jadi hortikultura sebagai budidaya tanaman kebun. Komoditas di Desa Serang yang khas dan menjadi komoditas unggulan dengan produktifitas yang besar yaitu cabai merah, kobis, tomat, kentang, dan stroberi. Ketahanan pangan lokal secara mikro dan makro di Desa Serang didukung dengan kondisi daerah pegunungan dengan letak ketinggian $750 \mathrm{~m}-1400 \mathrm{dpl}$ dan setiap rumah memiliki pekarangan lahan yang relatif cukup luas, sehingga dapat dimanfaatkan untuk menanam berbagai jenis tanaman holtikultura. Menurut Wirawan dan Nurdin (2013) ketersediaan pangan sangat tergantung pada budaya perilaku memproduksi, mendistribusi dan mengkonsumsi makanan itu sendiri. Dengan demikian makanan merupakan kebudayaan yang meliputi unsur kepercayaan, keyakinan, selera, kebiasaan, nilai-nilai, tahayul-tahayul, mitos dan lain sebagainya, yang merupakan pedoman bagi masyarakat yang meyakininya untuk mengkonsumsi.

Kearifan lokal (local wisdom) masyarakat Desa Serang adalah selalu kompak dan bekerjasama (guyub) dalam usaha holtikultura, seperti mulai dari perencanaan penanaman dengan komoditas tertentu untuk di tanam secara massal sesuai permintaan pasar, dan dalam proses penjualan hasil panen, semua dilakukan melalui keputusan bersama secara musyawarah dan mufakat dalam kelembagaan Gabungan kelompok tani (Gapoktan) Serang Sukses Makmur 
(SSM) dan kelompok "Tani Makmur". Setiap masyarakat (kepala keluarga) memiliki iuran wajib sebanyak seribu rupiah setiap hari yang dikumpulkan di kelompok tani, sebagai dana tabungan bersama (kas kelompok) untuk dana sosial serta dana talangan. Menurut Widodo dan Suradi (2011) organisasi dan kearifan lokal, yang tumbuh dan berkembang di masyarakat, perlu diberikan ruang gerak yang luas agar dapat mengekspresikan dan mengartikulasikan berbagai kebutuhan masyarakat sebagai keswadayaan masyarakat dan peran aktifnya dalam pembangunan, khususnya bagi pembangunan kesejahteraan sosial. Muhtar (2012: 101-116) menyatakan melalui rembug kelompok dihasilkan rencana kegiatan yang akan di lakukan, yaitu memanfaatkan sumber daya lokal, meningkatkan peran lembaga lokal, meningkatkan usaha simpan pinjam, dan penanganan permasalahan kesejahteraan sosial.

Persaingan antar kelompok atau antar petani holtikultura di Desa Serang tidak terjadi secara terbuka baik dari segi jenis komoditas tanaman, pemasaran hasil panen, maupun harga dan keutungan. Jika terjadi kegagalan panen dan kerugian ditanggung bersama, karena semua dilakukan secara kompak serta mufakat sebagai kearifan lokal. Kegagalan panen disebabkan oleh serangan hama, hasil produksi berlimpah tetapi permintaan sedikit, dan biaya modal produksi lebih besar dibandingkan dengan hasil penjualan.

Masyarakat petani di Desa Serang dalam pemasaran dan harga hasil panen dikuasasi oleh tengkulak sebagai pembeli tunggal, sehingga harga ditentukan dan tergantung pada tengkulak, serta petani tidak bisa memiliki akes ke pihak lain dalam pemasaran hasil panen karena ikatan kerjasama yang sudah terjalin lama antara petani dengan tengkulak menjadi solidaritas untuk saling menghargai serta tidak ingin ada yang mengkhianati komitmen. Peran tegkulak selalu hadir dalam rantai distribusi pemasaran, tidak bisa dihindari dan dilepaskan. Menurut Mardianto et al. (2005: 116-131) pedagang pengumpul yang disebut tengkulak telah ikut membantu memberikan kemudahan pada petani dalam memasarkan hasil panenya. Nurchayati dan Hikmah (2014) menyatakan dalam distribusi pemasaran tidak dapat dipisahkan peran dari tengkulak atau bakul.

Terdapat keuntungan dan kerugian dengan adanya pembeli atau tengkulak yang memborong hasil panen. Keuntungannya petani tidak susah memasarkan, tidak ada beban resiko distribusi dan selalu ada kepastian pembeli. Kerugianya adalah ketergantungan pada tengkulak yang menentukan harga, para petani tidak memiliki harga tawar, hasil panen harus segera di jual supaya tidak membusuk, akses pasar terbatas, dan terikat komitmen untuk tidak menjual hasil panen ke pembeli lainnya.

Jika terjadi kegagalan panen, harga yang rendah dan mengalami kerugian, kelompok tani di Desa Serang tetap dapat bertahan untuk memenuhi kebutuhan sehari-hari yaitu dari komoditas lain yang ada dipekarangan rumah, hal inilah yang menjadi katahanan pangan dan kearifan lokal yang dapat menjadi keunikan dan daya tarik untuk agrowisata di Desa Serang. Menurut Purwanto (2012: 294317) ketahanan pangan merupakan suatu sistem yang terdiri dari ketersediaan, distribusi, dan konsumsi yang saling berkaitanuntuk menjamin pasokan pangan dan memenuhi kebutuhan seluruh penduduk, baik dari segi kuantitas, kualitas, keragaman serta keamanannya pangan dalam jumlah dan kualitas yang cukup sepanjang waktu dengan harga yang terjangkau. Wirawan dan Nurdin (2013) menegaskan menjaga dan melestarikan lingkungan fisik, sosial, pengetahuan dan teknologi lokal dengan 'keuletan' adalah kearifan lokal yang mampu beradaptasi 
dengan perubahan menjadi potensi penting dalam mengambil kebijakan ketahanan pangan.

Pemerintah Desa Serang tidak memiliki lahan tanah bengkok yang bisa dijadikan modal tetap bagi desa atau masyarakat dalam meningkatkan produktifitas holtikultura sebagai ketahanan pangan yang mendukung sektor agrowisata. Masyarakat dan pemerintah Desa Serang tidak mengeluh dan merasa rugi, karena tetap mendapat fasilitas lahan yang disewakan oleh Perhutani. Namun untuk masa depan Desa Serang dalam mempertahankan dan mengembangkan ketahanan pangan holitkultura yang mendukung agriwisata, perlu mendapat lahan tetap sebagai tanah bengkok yang diberikan pemerintah daerah sebagai modal tetap ketahanan pangan. Hal ini direkomendasikan Mujiyadi (2012: 192204) bahwa (1) Tidak perlu ada pelarangan terhadap optimalisasi pemanfaatan lahan tidur sejenis; (2) Perlunya semacam penyuluhan yang memberikan rasa nyaman bagi para petani sebagai upaya antisipasi apabila sewaktuwaktu lahan yang sekarang dikelola akan dimanfaatkan oleh si pemilik lahan.

Masyarakat tani di Desa Serang memiliki masalah tentang posokan dan mahalnya harga pupuk dan bibit, sehingga keuntungan hasil produksi relatif rendah dan tidak stabil, kemudian masalah permodalan, pemasaran serta kerjasama. Banyaknya program pemberdayaan yang diterima masyarakat Desa Serang dari pemerintah pusat, pemerintah daerah, lembaga swadaya masyarakat, perguruan tinggi dan mahasiswa berupa kegiatan Kuliah Kerja Nyata (KKN) serta praktek kerja atau praktikum, masih belum komprehensif terintegrasi. Program pemberdayaan yang diberikan belum dapat meningkakan penguatan dan peningkatan kelembagaan petani, pemasaran, promosi dan kemitraan agrowisata.

Desa Serang sudah memiliki Badan Usaha Milik Desa yang bernama Serang
Makmur Sejahtera atau BUMDes SMS dengan unit usaha andalan yaitu kawasan agrowisata "LA" atau Lembah Asri sebagai lokasi sentra stroberi, sayuran, taman bunga, arena berkuda dan kawasan perkemahan hutan pinus yang sudah menjadi tujuan bagi wisatawan domestik dan luar negeri, instansi pemerintah, TNI atau Polri, organisasi, sekolah dan perguruan tinggi untuk melakukan kegiatan wisata, perkemahan, pelatihan dan permainan outbound, praktek kerja, praktikum dan penelitian dan studi banding, serta akses jalan ke lokasi wisata Gunung Selamet. Namun BUMDes Desa Serang masih membutuhkan penyuluhan, pelatihan dan pendampingan untuk pengembangan kelembagaan, menejerial organisasi, unit usaha dan pengelolaan keuangan serta tempat agrowisata yang potensial dan prospektif. Agrowisata di Desa Serang dapat dirancang dengan komunikasi pemasaran yang bersifat partisipatif dan inovatif dengan melibatkan semua pihak, terbuka bagi usaha semua masyarakat, sehingga BUMDes menjadi milik bersama, dari masyarakat oleh masyarakat dan untuk kesejahteraan masyarakat Desa Serang.

Strategi komunikasi pemasaran terintegrasi di agrowisata LA dapat dilakukan melalui program pemberdayaan yang berbasis ketahanan pangan holtikultura di Desa Serang. Komunikasi pemasaran terintegrasi membutuhkan peran dari berbagai pihak atau stakeholder yaitu pemerintah, akademisi, dan lembaga masyarakat untuk mengidentifikasi, menganalisis, membuat perencanaan dari kajian berbagai bidang khususnya ilmu komunikasi. Menurut Santi (2006: 62-70), semua unsur komunikasi pemasaran harus dilakukan dengan terpadu, baik terpadu dalam arti program maupun terpadu dalam arti subyek dan obyek pelakunya agar komunikasi yang terjadi adalah two-ways communication. Belch dan Belch (2004) menjelaskan komunikasi pemasaran terpadu memiliki nilai penting yaitu 
rencana yang komprehensif dan mengevaluasi peran strategis dari berbagai disiplin ilmu komunikasi misalnya, periklanan, respon khalayak secara langsung, promosi penjualan, dan hubungan masyarakat dengan menggabungkan disiplin ilmu lainnya untuk memberikan kejelasan, konsistensi, dan dampak komunikasi secara maksimal. Solsolay (2016: 86-99) menyarankan peran pemerintah untuk membuat langkahlangkah strategis dalam konsep dasar komunikasi pemasaran terpadu atau Integrated Marketing Communication (IMC) yaitu dengan mendekati khalayak seperti pemerintah, sektor swasta, stakeholder, masyarakat dan media sebagai elemen dari pendukung komunikasi pemasaran. Menurut Takalani (2015: 90-97), IMC secara keseluruhan menyediakan kerangka kerja organisasi yang harus berkomunikasi dengan para pemangku kepentingan (stakeholders) untuk mengendalikan, merencanakan, melaksanakan dan mengevaluasi secara terkoordinasi, serta terukur. Program komunikasi pemasaran dilaksankan secara persuasif terhadap konsumen, pelanggan, investor dan khalayak internal serta eksternal lainnya yang relevan. Hanifah dan Unayah (2011: 85-100) menegaskan perlunya pemanfaatan tenaga lokal sebagai pendamping dalam implementasi program pemberdayaan dengan sentuhan moralspiritual, disamping monitoring dan evaluasi dilaksanakan secara berkelanjutan dari aparat pemerintah. Program pemberdayaan harus didasarkan kebutuhan penerima pelayanan, dalam arti bersifat "buttom up" dan bukan "top down". Menurut Nursalam (2010) implementasi kebijakan peningkatan produksi tanaman lokal belum optimal sehingga masih terdapat kesenjangan yang besar antara produksi dengan potensi tanaman pangan lokal. Beberapa masalah mendasar yang perlu mendapat perhatian yaitu masalah kurangnya pelibatan para pelaksana pada tataran operasional, masalah koordinasi pelaksanaan antar unit yang terkait; dan masalah klasik yaitu anggaran yang memadai untuk program peningkatan produksi tanaman pangan lokal.

Dengan demikian strategi komunikasi pemasaran yang dapat dilakukan di agrowisata berbasis ketahanan pangan Desa Serang yaitu: (1) Forum dialog yang melibatkan kerjasama semua pihak yaitu stakeholder baik pemerintah daerah, perguruan tinggi maupun lembaga swadaya masyarakat dengan Badan Usaha Milik Desa (BUMDes) yang menjadi pusat lembaga ekonomi masyarakat; (2) Subjek pelaku melakukan perencanan dan pelaksanaan program melalui kajian dan riset untuk mengidentifikasi dan menganalisis permasalahan, potensi dan solusi program pemasaran; (3) Melaksanakan perencanaan dan pelaksanaaan program pemasaran serta promosi secara langsung dengan membuka akses kerjasama atau kemitraan dengan instansi serta swasta, maupun melalui media seperti membuat brosur, spanduk, dan baliho yang disebar atau dipasang di tempat strategis supaya mendapat perhatian publik. Membuat media iklan di surat kabar, mengembangkan media informasi teknologi dan komunikasi (TIK) seperti website serta media sosial lainnya; (4) Membentuk dan melatih tim strategi pemasaran dan promosi serta humas yang bertugas melakukan pelayanan kepada pengunjung; (5) Memanfaatkan setiap pergelaran acara rutin di wilayah agrowisata seperti kegiatan kemah, pelatihan instansi, kunjungan mahasiswa, dan festival nasional untuk memasarkan dan mempromosikan produk hasil pertanian, makanan khas, kesenian, dan fasilitas yang disediakan; (6) Menyelenggarakan berbagai kegiatan seperti pergelaran seni, budaya dan bazaar atau pasar produk pertanian holtikultura dengan mempromosikan serta melibatkan semua pihak. Kegiatan yang sudah menjadi agenda tahunan dan harus dilestarikan adalah Festival Gunung 
Slamet (FGS) yang dilaksanakan pada tanggal 13-15 Oktober 2016 yang diikuti oleh sembilan kabupaten meliputi Kabupaten Purbalingga, Banjarnegara, Banyumas, Cilacap, Kebumen, Pemalang, Tegal, dan Pekalongan. Kegiatan festival Gunung Selamet yaitu (1) Ruwatan Ritual Pengambilan Air Tuk Sikopyah dan arakarakan gunung hasil bumi dan ruwat bumi.

(2) Gelar seni berupa wayang kulit dan music jazz di atas gunung di kebun stroberi dan rest area di Desa Serang. (3) Parade seni budaya dilaksanakan di alunalun Purbalingga. (4) Pelaksanaan konggres Gunung Selamet. Tujuan festival dan konferensi adalah memeriahkan Festival Gunung Slamet sebagai pergelaran bertingkat nasional dengan kegiatan upacara adat dan seni budaya yang dimiliki oleh daerah sekitar kabupaten Purbalingga di kawasan Banyumas, Cilacap, Kebumen, Pemalang, Tegal, Pekalongan untuk memberikan hiburan bagi masyarakat sekaligus mendukung kegiatan Pariwisata.

Strategi pemasaran dan promosi agrowisata Lembah Asri (LA) yang berbasis ketahanan pangan dapat didukung oleh adopsi inovasi seperti (1) Membentuk tim promosi dan pemasaran tentang Agrowisata LA dengan memberikan pelatihan serta pendampingan pengelolaan dan pengembangan website dan media sosial lainnya seperti Facebook (FB) oleh kelompok usaha, petani, pemuda dan pengurus agrowisata. Media website menjadi strategi promosi dan pemasaran yang menarik, interaktif, informatif dan efektif. Membuat media presentasi, profil agrowisata, iklan di koran, menyebarkan brosur, memasang baliho dan spanduk di tempat strategis.

Menurut Mukaromah dan Sari (2016: 35-42) adanya media baru dapat digunakan oleh pekerja humas (public relations officer) untuk melaksanakan fungsinya dalam berkomunikasi, memberikan informasi dengan stakeholder. Chrismardani (2014: 176-
189) menegaskan pemasaran dengan menggunakan media online terbukti dapat membangun hubungan dengan pelanggan, meningkatkan penjualan, mengkomunikasikan informasi, dan melakukan pelayanan secara efektif serta efisien. (2) Hasil produksi sayuran dapat disimpan di gudang penyimpanan dengan teknologi pengatur suhu pendingin yang disebut cold storage supaya dapat disimpan lebih lama, tidak tergantung pada tawaran tengkulak, dan dapat mempertahankan harga pasar. (3) Pengemasan dan label produk hasil sayuran dan buah-buahan dapat mempergunakan alat wrapping machine, supaya lebih menarik, hasilnya dapat disimpan dalam tempat atau toko dengan pengatur suhu pendingin supaya tahan lama dan memiliki nilai jual lebih tinggi. (4) Proses pengolahan dan pengemasan buah stroberi menjadi manisan dan getuk harus di dukung oleh peralatan yang lebih modern seperti alat pengering air dan minyak, label produk dan alat pengemasannya supaya lebih menarik, steril, segar, memiliki nilai jual yang lebih tinggi dan kompetitif. (5) Membentuk dan melatih tim public relation, pemasaran, promosi dan kerjasama untuk mengembangkan agrowisata dan produk hasil ketahanan pangan, melakukan pelayanan kepada pengunjung. Hughes dan Fill (2005: 85-100) menyebutkan beberapa strategi komunikasi pemasaran yaitu pendekatan yang terkoordinasi dalam melaksanakan komunikasi, melanjutkan kemajuan dalam media dan teknologi komunikasi, media yang beragam sebagai peluang baru untuk saluran komunikasi, pengaruh etika dan tanggung jawab sosial perusahaan, dan ketersediaan data informasi untuk pelanggan secara rinci dengan teknologi serta ada evaluasi untuk mengukur efektivitas. Marsigit (2010: 256264) menyatakan bahwa pemberdayaan sektor pasca panen, pengolahan dan pemasaran hasil pertanian yang dari berbagai penelitian banyak meningkatkan 
nilai tambah ekonomi seperti peningkatan pendapatan dan nilai tambah sosial yaitu peningkatan dan penciptaan lapangan kerja. Menurut Purwanto (2012: 294-317) inovasi tersebut meliputi varitas unggul bergizi tinggi, teknologi pasca panen terutama penyimpanan, serta teknologi untuk meningkatkan nilai tambah dan mengangkat citra pangan tradisional menjadi komoditas yang bergengsi, menarik disajikan, serta enak dan praktis dikonsumsi.

Pengembangan lokasi agrowisata sebagai unit usaha strategis dan unggulan dari BUMDes Desa Serang memiliki dampak positif yaitu membuka lapangan kerja, meningkatkan penghasilan dan kesejahteraan masyarakat. Dampak negatifnya masyarakat yang berada jauh dari lokasi tempat rest area agrowisata kurang memiliki kesempatan untuk aktif mengelola baik sebagai pengurus BUMDes, pengelola agrowisata, maupun berjualan. Sehingga masyarakat atau kelompok tani yang berlokasi di atas dekat dengan rest area lebih diuntungkan untuk dapat berjualan, menjadi pengurus BUMDes dan pengelola agrowisata. Terdapat dominasi dari beberapa pengurus BUMDes dan pengelola agrowisata, karena kurangnya pemahaman dan keterampilan dalam pengelolaan pengurus, anggota, keuangan, pelayanan pada publik dan pengembangkan unit usaha. Menurut Ramadana et al. (2013: 1068-1076) BUMDes seharusnya dapat menciptakan kemandirian masyarakat desa baik dari segi permodalan, usaha ekonomi dan pemasaran.

Dengan demikian agrowisata di Desa Serang memiliki potensi konflik kepentingan dan ekonomi yang dapat medegradasi kearifan lokal yang selama ini sudah ada yaitu kebersamaan, kegotong-royongan dan kemufakatan di masyarakat untuk menanam komoditas holtikultura, memasarkan hasil panen serta tidak ada persaingan terbuka. Menurut hasil penelitian Susanto (2012) ada dampak positif maupun negatif adanya alih fungsi lahan pertanian menjadi tempat lokasi wisata di Desa Serang yaitu dampak positifnya dapat meningkatnya tingkat pendapatan, kesejahteraan masyarakat, terbukanya lapangan kerja baru selain menjadi petani. Dampak negatifnya terjadinya persaingan antar warga dalam menarik para wisatawan dan terjadinya konflik perebutan lahan dan hak waris, berubahnya pola kehidupan masyarakat yang dulunya bekerja di ladang dan bertani menjadi jarang atau tidak lagi bertani serta berganti profesi bekerja di sektor pariwisata.

Perkembangan agrowisata dan inovasi teknologi dapat diterapkan untuk meningkatkan pemasaran, promosi dan nilai tambah produksi, tetapi tidak menghilangkan ciri khas dan keunikan sebagai kearifan lokal masyarakat Desa Serang. Agrowisata di Desa Serang yang berbasis ketahanan pangan, harus memiliki komunikasi pemasaran dan promosi yang sesuai dengan motto Sapta Pesona pariwisata yaitu yaitu aman, tertib, bersih, sejuk, indah, ramah tamah dan kenangan.

Menurut Mardikanto dan Soebianto (2012) dalam proses perubahan memerlukan inovasi berupa ide, produk, metode, peralatan dan teknologi dengan kajian serta pengembangan kebiasaan, nilai, tradisi pada kearifan lokal (indigenous technology). Proses untuk memfasilitasi dan mendorong masyarakat menjadi pelaku utama dalam memanfaatkan lingkungan untuk mencapai keberlanjutan (sustainable development) jangka panjang.

Handayani et al. (2013: 97-108) merekomendasikan pengembangan sistem inovasi daerah harus dapat (1) Meningkatkan nilai kemanfaatan kebijakan dalam mendukung perkembangan, peningkatan kualitas maupun kuantitas sarana prasarana perdagangan dan jasa secara berkelanjutan. (2) Menciptakan budaya berinovasi untuk mendukung perkembangan sektor perdagangan dan 
jasa. (3) Mendorong perkembangan lembaga iptek untuk menjalankan riset kebijakan dan infrastruktur yang memadai untuk menciptakan budaya berinovasi. (4) Menciptakan peningkatan perekonomian rakyat yaitu klaster usaha ekonomi berbasis inovasi lokal yang didukung dengan sistem tata kelola yang baik.

Berdasarkan hasil dan pembahasan penelitian, dapat dibuat matrik analisis SWOT beserta strategi komunikasi pemasaran terintegrasi dalam agrowisata berbasis ketahanan pangan di Desa Serang Kecamatan Karangreja Kabupaten Purbalingga yang disajikan di Gambar 1 .

David (2006) menjelaskan analisis SWOT yaitu: (1) Kekuatan (strenghts) adalah kompetensi sumber daya, keterampilan, atau keungulan-keungulan kompetitif. (2) Kelemahan (weakness), adalah keterbatasan dalam sumber daya, fasilitas, keterampilan, kapabilitas dan kemampuan menejemen, pemasaran, serta keuangan yang secara efektif menghambat kinerja. (3). Peluang (opportunities) adalah situasi penting yang mengguntungkan dalam lingkungan dan sumber peluang seperti perubahaan teknologi dan meningkatnya hubungan kerjasama dengan instansi lain dan pembeli atau pemasok. (4). Ancaman (threats) adalah situasi penting yang tidak menguntungan yang berada di luar atau sekitar organisasi.
Menurut Rangkuti (2009) analisis SWOT dapat dibuat strategi sebagai berikut (1) Strategi SO (strength and oppurtunity) dengan memanfaatkan seluruh kekuatan untuk merebut dan memanfaatkan peluang. (2) Strategi ST (strength and threats) menggunakan kekuatan yang dimiliki untuk mengatasi ancaman. (3) Strategi WO (weakness and oppurtunity) berdasarkan pemanfaatan peluang dengan cara meminimalkan kelemahan. (4) Strategi WT (weakness and threats) berdasarkan kegiatan yang bersifat defensif dengan meminimalkan kelemahan dan menghindari ancaman. Hasil analisis SWOT dapat dibuat model strategi komunikasi pemasaran terintegrasi untuk agrowisata berbasis ketahanan pangan di Desa Serang Kecamatan Karangreja Kabupaten Purbalingga. 


\begin{tabular}{|c|c|c|}
\hline Fakor Eksternal & $\begin{array}{l}\text { Strength (S) } \\
\text { 1.Masyarakat memiliki budaya secara } \\
\text { turun temurun untuk bekerja keras } \\
\text { melakukan budidaya tanam } \\
\text { holtikultura di pekarangan rumah dan } \\
\text { di ladang perkebunan. } \\
\text { 2.Masyarakat desa memiliki kearifan } \\
\text { lokal yaitu kekompakan (guyub) } \\
\text { untuk membuat keputusan bersama } \\
\text { secara musyawarah dalam } \\
\text { menentukan komoditas yang ditanam, } \\
\text { pemasaran, untung dan rugi/gagal } \\
\text { ditanggung bersama. Sehingga tidak } \\
\text { ada persaingan terbuka antar } \\
\text { masyarakat/kelompok dalam } \\
\text { menanam dan menjual hasil panen. } \\
\text { 3.Memiliki daya tahan terhadap krisis } \\
\text { ekonomi dan gagal panen karena } \\
\text { memiliki ketahanan pangan di } \\
\text { pekarangan rumah. }\end{array}$ & $\begin{array}{l}\text { Weakness (W) } \\
\text { 1.Masyarakat Desa Serang tidak } \\
\text { memiliki keberanian dan kemampuan } \\
\text { dalam proses keputusan BUMDes. } \\
\text { 2.Masyarakat Desa Serang berpendidikan } \\
\text { relatif menengah (SMP) dan } \\
\text { kecenderungan menikah di usia dini } \\
\text { masih cukup tinggi, sehingga banyak } \\
\text { yang tidak melanjutkan pendidikan } \\
\text { formal. } \\
\text { 3.Belum dapat memaksimalkan hasil } \\
\text { panen dan produk pengolahan menjadi } \\
\text { produk makanan atau minuman yang } \\
\text { diolah serta dikemas lebih menarik yang } \\
\text { dapat memiliki keuntungan lebih besar. } \\
\text { 4.Masih lemahnya pengelolaan } \\
\text { kepengurusan, keanggotan, keuangan, } \\
\text { promosi, pemasaran dan pengembangan } \\
\text { unit usaha bagi kemajuan agrowisata } \\
\text { dan BUMDes. }\end{array}$ \\
\hline $\begin{array}{l}\text { Opportunities (O) } \\
\text { 1.Desa Serang berlokasi di } \\
\text { pegunungan dengan sector } \\
\text { agrowisata yang potensial dan } \\
\text { prospektif dengan banyak } \\
\text { kunjungannya, hasil panen } \\
\text { sayuran dan stroberi, tempat } \\
\text { kegiatan pelatihan, perekemahan, } \\
\text { studi banding dan penelitian baik } \\
\text { dalam maupun luar negeri, } \\
\text { sehingga membuka kesempatan } \\
\text { kerja, memacu produktifitas } \\
\text { pertanian, meningkatkan } \\
\text { penghasilan dan kesajehtaran } \\
\text { masyarakat. } \\
\text { 2.Memaksimalkan banyaknya } \\
\text { kegiatan pemberdayaan dan } \\
\text { pengabdian masyarakat, riset, } \\
\text { praktek kerja dari pemerintahan, } \\
\text { perguruan tinggi, lembaga } \\
\text { swadaya masyarakat dan } \\
\text { perusahaan swasta. }\end{array}$ & $\begin{array}{l}\text { Strategi SO } \\
\text { 1.Membuat forum komunikasi para } \\
\text { stakeholder yaitu pemerintah desa dan } \\
\text { daerah, akademisi (perguruan tinggi), } \\
\text { lembaga swadaya masyarakat dan } \\
\text { media/jurnalis untuk melakukan } \\
\text { dialog \& kajian berbagai disiplin } \\
\text { ilmu, membuat program } \\
\text { pemberdayaan, strategi pemasaran } \\
\text { serta promosi bagi agrowisata Desa } \\
\text { Serang. } \\
\text { 2.Mempertahankan } \\
\text { mengembangkan pergelaran seni, } \\
\text { budaya, serta pasar rakyat yang } \\
\text { selalu diadakan setiap tahun, seperti } \\
\text { Festival dan konferensi Gunung } \\
\text { Selamet. } \\
\text { 3.Hasil dialog, kajian dan riset } \\
\text { dilakukan sosialisasi, kesepakatan } \\
\text { untuk kegiatan pemberdayaan, } \\
\text { pemasaran dan promosi agrowisata } \\
\text { serta festival Gunung Selamet. }\end{array}$ & $\begin{array}{l}\text { Strategi WO } \\
\text { 1.Stakeholder dari pemerintah, perguruan } \\
\text { tinggi dan lembaga sosial mengadakan } \\
\text { sosialisasi dan pelatihan mekanisme } \\
\text { musyawarah untuk membuat } \\
\text { perencanaan dan pelaksanaan } \\
\text { pembangunan, meingkatkan kesadaran } \\
\text { dan pengetahuan tentang hak serta } \\
\text { kewajiban pembangunan di desa. } \\
\text { 2.Pelatihan dan pendampingan tentang } \\
\text { pengelolaan pengurus, keuangan, } \\
\text { promosi serta pemasaran dalam } \\
\text { BUMDes dan agrowisata. } \\
\text { 3.Pelatihan dan pendampingan dalam } \\
\text { membuat media promosi dan pemasaran } \\
\text { melalui internet, bosur, baliho, papan } \\
\text { informasi dan, meningkatkan kualitas } \\
\text { pelayanan pada pengunjung agrowisata. } \\
\text { 4.Penerapan adopsi inovasi pada produk } \\
\text { usaha dan pemasaran. }\end{array}$ \\
\hline $\begin{array}{l}\text { Threats }(\mathbf{T}) \\
\text { 1.Masyarakat Desa Serang tidak } \\
\text { memiliki tanah bengkok untuk } \\
\text { ladang perkebunan sebagai modal } \\
\text { tetap, karena selama ini untuk } \\
\text { pertanian skala besar menyewa dari } \\
\text { tanah Perhutani. Sehingga } \\
\text { ketergantungan sangat tinggi dan } \\
\text { tidak ada jaminan jika sudah tidak } \\
\text { dijinkan atau diperpanjang lagi. } \\
\text { 2.Harga hasil panen sangat } \\
\text { tergantung kepada kekuasaan } \\
\text { tengkulak, sehingga masyarakat } \\
\text { tidak bisa memiliki harga tawar. } \\
\text { 3.BUMDes dan agrowisata } \\
\text { didominasi kelompok tertentu } \\
\text { belum melibatkan partisipasi semua } \\
\text { warga untuk menjadikan usaha } \\
\text { bersama, sehingga dapat } \\
\text { menimbulkan konflik yang } \\
\text { mendegradasi kearifan lokal. }\end{array}$ & $\begin{array}{l}\text { Strategi ST } \\
\text { 1.Masyarakat dan pemerintah desa } \\
\text { melakukan komunikasi partisipatif } \\
\text { dengan pemerintah daerah, dan } \\
\text { Perhutani melalui musyawarah untuk } \\
\text { meminta jaminan pemanfaatan } \\
\text { ladang/kebun sebagai lahan produktif } \\
\text { untuk pertanian holtikultura dan } \\
\text { kawasan agrowisata tetapi tetap } \\
\text { menjaga dan memelihara } \\
\text { kelestariannya secara adil. } \\
\text { 2.Kelompok tani, BUMDes dan } \\
\text { pemerintah desa diberikan pelatihan } \\
\text { dan pembentukan tim } \\
\text { penyelenggaraan dan pendampingan } \\
\text { festival seni budaya, pasar rakyat, } \\
\text { pameran hasil produk holtikultura. } \\
\text { 3.Melakukan pelatihan dan } \\
\text { pendampingan pengelolaan } \\
\text { organisasi, keuangan dan evaluasi } \\
\text { BUMDes dan Agrowisata. }\end{array}$ & $\begin{array}{l}\text { Strategi WT } \\
\text { 1. Masyarakat diberikan sosialisasi dan } \\
\text { penyuluhan oleh stakeholder } \\
\text { pemerintah. perguruan tinggi dan } \\
\text { lembaga sosial tentang pentingnya } \\
\text { pemeliharaan dan menjaga kelestarian } \\
\text { alam lingkungan lahan pertanian dan } \\
\text { hutan. Memelihara kerjasama dan } \\
\text { kepercayaan dengan Pehutani untuk } \\
\text { tetap memberikan ijin menyewa tanah } \\
\text { pertanian holtikultura dan hutan } \\
\text { lindung untuk dapat dimanfaatkan } \\
\text { secara aman, produktif dan adil. } \\
\text { 2.Masyarakat diberikan sosialisasi } \\
\text { strategi pemasaran terintegrasi yaitu } \\
\text { merencanakan dan melaksanakan loby, } \\
\text { perluasan akses, kerjasama atau } \\
\text { kemitraan dengan berbagai pihak } \\
\text { untuk membantu pemasaran produksi } \\
\text { panen dan lokasi agrowisata. }\end{array}$ \\
\hline
\end{tabular}




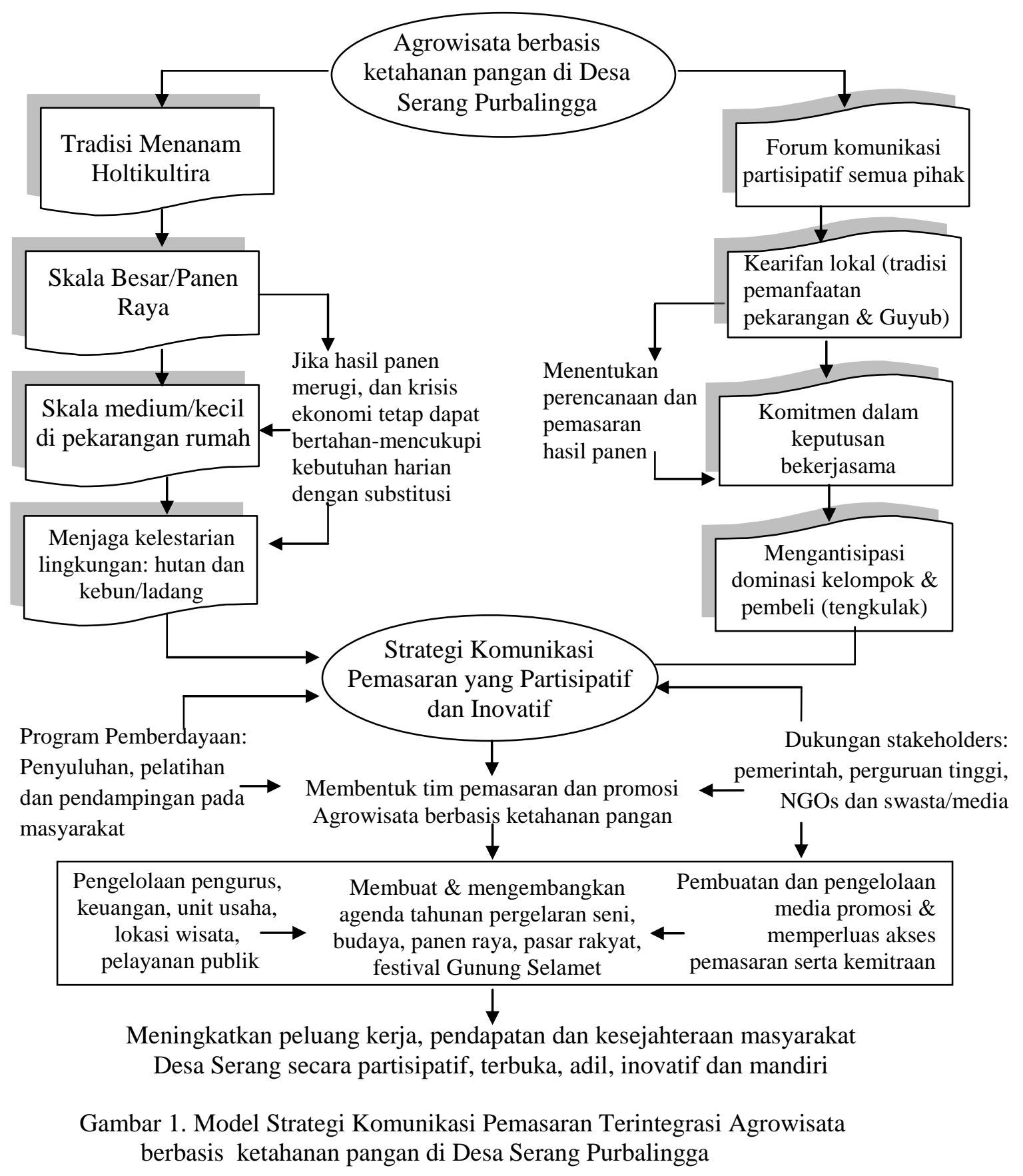




\section{Penutup}

Masyarakat Desa Serang memiliki kearifan lokal yaitu (1) Tradisi memanfaatkan lahan pekarangan untuk tanaman holtikultura yang mampu memenuhi kebutuhan harian dan menjadi ketahanan pangan lokal ketika terjadi krisis ekonomi atau kegagalan panen raya. (2) Kebersamaan untuk melakukan komunikasi dan koordinasi dalam proses pengambilan keputusan bersama secara mufakat dalam perencanaan penanaman dan pemasaran hasil panen. Sehingga tidak ada persaingan diantara masyarakat petani holtikultura secara terbuka. Jika ada keuntungan, kerugian atau gagal panen akan menjadi konsekwensi bersama.

Pemasaran hasil panen holtikultura masih memiliki ketergantungan kepada tengkulak yang sudah sejak lama menjalin kerjasama dan membentuk solidaritas, sehingga para petani tidak mau mengkhianati dengan menjual hasil panen ke pihak lainnya. Ikatan komunikasi pemasaran dengan tengkulak satu sisi memiliki dampak positif yaitu masyarakat dimudahkan dalam penjualan hasil panen, tidak harus mendistribusikan ke luar desa dengan jarak yang cukup jauh dan menimbulkan resiko pengeluaran tambahan. Dampak negatifnya harga hasil panen ditentukan oleh tengkulak, sehingga masyarakat tidak dapat memiliki daya tawar harga, ketergantungan yang mengikat kepada tengkulak dan tidak dapat menjual ke pihak lainnya.

Desa Serang sebagai lokasi agrowisata berbasis ketahanan pangan dengan hasil holtikultura khususnya stroberi, lingkungan alam yang dijadikan tempat persinggahan (rest area), tempat wisata, taman bunga, belanja sayuran dan buah-buahan, taman bermain dan pelatihan outbound, perkemahan dan untuk penelitian ilmiah. Agrowisata berbasis ketahanan pangan lokal memiliki potensi dan prospek yang menguntungkan yaitu membuka pekerjaan, meningkatkan pengahasilan dan kesejahteraan masyarakat desa. Namun memiliki potensi adanya persaingan dan konflik yang dapat medegradasi kearifan lokal disebabkan ada dominasi pengelolaan agrowisata dan BUMDes, belum maksimalnya pengelolaan kepengurusan, tempat wisata, promosi, pemasaran, pelayanan publik, pengembangan unit usaha dan keuangan. Kemudian masyarakat yang berada di lokasi jauh dari tempat agrowisata kurang memiliki akses dan kesempatan yang sama untuk dapat berpartisipasi dan memanfaatkan agrowisata.

Strategi komunikasi pemasaran terintegarasi di agrowisata Desa Serang yaitu dengan membuka forum dialog sambung rasa atau sarasehan sebagai komunikasi partisipatif yang melibatkan semua pihak atau stakeholder antara lain masyarakat kelompok usaha dan kelompok tani, pemerintah desa, pemerintah daerah, perguruan tinggi dan lembaga swadaya masyarakat untuk (1) Membuat perencanaan dan pelaksanaan promosi serta pemasaran secara terpadu melalui kajian dan riset untuk mengidentifikasi permasalahan, menganalisis potensi dan prospek untuk peningkatan kesejahteraan masyarakat. (2) Melaksanakan progam pemberdayaan untuk menjalankan strategi pemasaran dengan sosialisasi, pelatihan, dan pendampingan pada masyarakat kelompok usaha, kelompok tani, pengurus BUMDes dan agrowisata dapat bekerjasama menjadi tim untuk meningkatkan pengelolaan kepengurusan, keuangan, tempat wisata, pengembangan usaha, pelayanan publik, pembuatan iklan promosi di media baik website, facebook, iklan di koran, membuat brosur, papan informasi, baliho dan spanduk di tempat strategis. (3) Menyelenggarakan pergelaran seni, budaya, panen raya, dan pasar rakyat untuk menjadi agenda rutin tahunan yang didukung pemasaran, promosi secara langsung maupun melalui media sosial. (4) Meembentuk tim promosi dan pemasaran agrowisata supaya dapat dikembangkan serta membuka akses 
kerjasama atau kemitraan dengan pemerintah, swasta atau investor dan perguruan tinggi.

\section{Daftar Pustaka}

Belch, G.E., and Michael, A. B. (2004).

Advertising and Promotion:

An Integrated

Marketing

Communications Perspective.

Boston: McGraw-Hill.

David, F.R. (2006). Manajemen Strategis. Jakarta: Salemba Empat.

Miles, M.B, and Huberman A.M. (2007). Analisis Data Kualitatif. Rohidi TR, penerjemah. Jakarta: UI Press.

Mardikanto, T dan Soebianto, P. (2012). Pemberdayaan Masyarakat dalam Perspektif Kebijakan Publik. Bandung: Alfabeta.

Rangkuti, F. (2009). Analisis SWOT Teknik Membedah Kasus Bisnis. Jakarta: Gramedia Pustaka Utama.

Syahyuti. (2006). Tiga Puluh Konsep Penting Dalam Pembangunan Pedesaan dan Pertanian : Penjelasan tentang Konsep, Istilah, Teori, Indikator serta Variabel. Jakarta: PT. Bina Rena Pariwara.

Ashari, Saptana, dan Purwantini, T.B. (2012). Potensi dan Prospek Pemanfaatan Lahan Pekarangan untuk Mendukung Ketahanan Pangan. Forum Penelitian Agro Ekonomi. 30(1).

Cepriadi, dan Yulida, R. (2012). Persepsi Petani terhadap Usaha Tani Lahan Pekarangan: Studi Kasus Usaha Tani Lahan Pekarangan di Kecamatan Kerinci Kabupaten Pelalawan. Indonesian Journal of Agricultural Economics (IJAE). 3(2).

Chrismardani, Y. (2014). Komunikasi Pemasaran Terpadu: Implementasi untuk UMKM. Jurnal Neo-Bis. 8(2).

Handayani, W., Sophianingrum, M., dan Nutriandini, U. (2013). Kajian Roadmap Pengembangan Sistem Inovasi Daerah (Sida) Kota Semarang. Riptek. 7(2).
Hanifah, A., dan Unayah, N. (2011). Kontribusi Organisasi Sosial dalam Pembangunan Kesejahteraan Sosial: Studi Kasus Organisasi Sosial di Kota Palembang Sumatera Selatan. Jurnal Penelitian dan Pengembangan Kesejahteraan Sosial. 16(1).

Hughes, G., and Fill, C. (2005). Marketing Communications 2005-2006. Oxford: Elsevier-Butterworth Heinemann.

Kuncoro, B., Djawahir R.S., Sulistiyoningsih, E.D., Suswanto, B., Sabiq, A., dan Sulaiman, .I.S. (2015). Model of Villagers Food Security Based on Local Wisdom. Proceeding. The $7^{\text {Th }}$ International Graduated Students and Scholars Conference in Indonesia (IGSSCI). The Knowledge, Power and Politic: Where is Humanity Heading to? 4-5 November.

Mardianto, S., Supriatna, Y., \& Agustin, N.K. (2005). Dinamika Pola Pemasaran Gabah dan Beras di Indonesia. Forum Penelitian Agro Ekonomi.Vol. 23(2).

Marsigit, W. (2010). Pengembangan Diversifikasi Produk Pangan Olahan Lokal Bengkulu untuk Menunjang Ketahanan Pangan Berkelanjutan. Agritech. 30(4).

Muhtar. (2012) Pengembangan Masyarakat dengan Memanfaatkan Aset Lokal: Studi Deskriptif di Desa Mlatirejo dan Desa Sendangmulyo yang berbatasan dengan Hutan Jati. Sosiokonsepsia. 17(1).

Mujiyadi, B. (2012). Pemberdayaan Masyarakat Miskin Pinggiran Kota: Studi Pekerjaan Sosial tentang Petani Penggarap di Lahan Sementara. Sosiokonsepsia. 17(2).

Mukaromah, dan Sari, D.V. (2016). Laman dan Reputasi Lembaga dalam Membangun Komunikasi dengan Stakeholders. The Messenger. 8(2). 
Nurchayati, dan Hikmah. (2014). Pola Distribusi Buah Lokal dan Buah Import: Studi Kasus pada Pedagang Buah di Kota Semarang. Seminar Nasional dan Call for Paper (Sancall 2014). Research Method and Organization Studies.

Nursalam. (2010). Implementasi Kebijakan Peningkatan Produksi Tanaman Pangan Lokal dan Ketahanan Pangan di Provinsi Nusa Tenggara Timur. Jurnal Administrasi Publik. 1(1).

Purwanto, AB. (2012). Penguatan Kapasitas Masyarakat dalam Ketahanan Pangan di Daerah Tetinggal: Studi Kasus di Distrik Agimuga, Mimika, Papua. Sosiokonsepsia. 17(3).

Ramadana, C.B., Ribawanto, H., Suwondo. (2013). Keberadaan Badan Usaha Milik Desa (BUMDes) sebagai Penguatan Ekonomi Desa (Studi di Desa Landungsari, Kecamatan Dau, Kabupaten Malang). Jurnal Administrasi Publik (JAP). 1(6).

Saliem, H.P. (2011). Kawasan Rumah Lestari (KRPL): Sebagai Solusi Pemantapan Katahanan Pangan. Makalah disampaikan pada Kongres Ilmu Pengetahuan Nasional (KIPNAS), di Jakarta tanggal 8-10 November.

Santi, S. (2006). Dari Komunikasi Pemasaran ke Komunikasi Pemasaran Terpadu. Jurnal Komunikologi. 3(2).

Soemirat, S., dan Ardianto, E. (2010). Dasar-Dasar Public Relation. Bandung: Remaja Rosdakarya.

Solsolay, S. (2016). Aktivitas Komunikasi Pemasaran Terpadu (IMC)
Pemerintah Kota Ambon Dalam Mengkomunikasikan Brand "Ambon City Of Music" Melalui Kegiatan Tiga Pilar IMC. The Messenger. $8(2)$.

Susanto, H. (2012). Dampak Sosial Alih Fungsi Lahan terhadap Pola Kehidupan Masyarakat Desa Serang Kecamatan Karangreja Purbalingga. Skripsi. Universitas Negeri Yogyakarta

Takalani, M. (2015). A review and analysis of the role of integrated marketing communication message typology in the development of communication strategies. African Journal of Marketing Management. 7(8).

Wibowo, A., Rohmat, Z., Padmaningrum, D., dan Utami, B.W. (2012). Strategi Komunikasi Masyarakat Samin dalam Membangun Ketahanan Pangan Lokal. Jurnal Ilmu Komunikasi. 10(3).

Wirawan, B., \& Nurdin BV. (2013). Kearifan Lokal untuk Kebijakan Ketahanan Pangan : Studi Kasus Di Kampung Karta Kecamatan Tulang Bawang Udik Kabupaten Tulang Bawang Barat. Jurnal Ilmiah Administrasi Publik dan Pembangunan. 4(1).

Kemenristek RI. (2006). Buku Putih Penelitian, Pengembangan dan Penerapan Ilmu Pengetahuan dan Teknologi Bidang Ketahanan Pangan Tahun 2006.

Undang-Undang Nomor 41 tahun 2009 tentang Perlindungan Lahan Pertanian Pangan Berkelanjutan.

Undang-Undang Rublik Indonesia Nomor 18 tahun 2012 tentang Pangan. 